\title{
Institutionalization, Policy Adaptation and European Foreign Policy Cooperation
}

\author{
MICHAEL E. SMITH \\ Georgia State University
}

\begin{abstract}
The expansion of European Union (EU) foreign policy cooperation since 1970 presents a number of puzzles for theorists of regional integration and International Relations. It is not directed by supranational organizations, does not involve bargaining over policy alternatives, and is not dominated by the largest EU states. Nor do the EU's common foreign policy decisions reflect 'lowest common denominator' preferences. Instead, cooperation has been achieved through decentralized institutional mechanisms, involving processes associated with both intergovernmental and social constructivist theories. This article first explains how changes in institutional context - in terms of intergovernmental, transgovernmental and supranational procedures affect the propensity for cooperation. It then links processes of institutionalization to an expansion of foreign policy cooperation among EU member states. Finally, it explores three policy areas (the Middle East, South Africa and nuclear non-proliferation) where EU states have adjusted their national foreign policies in line with EU foreign policy norms.
\end{abstract}

Key Words - Common Foreign and Security Policy • European Union foreign policy • European Political Cooperation • institutionalization $\bullet$ international cooperation

The Maastricht Treaty on European Union clearly marks a new era in the theory and practice of European integration. Much of the scholarly attention in this area focuses on the European Union's (EU) socioeconomic policy domains, primarily in terms of developing the single European market (Stone Sweet and Sandholtz, 1998). ${ }^{1}$ This achievement, however, tends to overshadow an increasingly prominent area of European integration - the pursuit of a common foreign policy. Foreign policy cooperation has been

European Journal of International Relations Copyright (C) 2004

SAGE Publications and ECPR-European Consortium for Political Research, Vol. 10(1): 95-136 DOI: $10.1177 / 1354066104040570]$ 
discussed in the EU since the 1950s, and led to European Political Cooperation (EPC) in 1970 and its transition to the Common Foreign and Security Policy (CFSP) 20 years later. Although skeptics can cite a variety of cases where the EU was unable to speak with a single voice in world affairs (Gordon, 1997-8; Zielonka, 1998; Hoffman, 2000), the development of EPC/CFSP has in fact resulted in a significant level of foreign policy coordination among EU states since 1970 (for a recent extensive survey, see Ginsberg, 2001). The EU's achievement in this domain is even more unique when compared to the feeble attempts at instituting political dialogue in other regional organizations. ${ }^{2}$

European foreign policy cooperation also involves unique processes in terms of institutional development and decision-making that can shed light on fundamental debates concerning European integration and International Relations (IR) theory. For theorists of European integration, the debate involves the effects of intergovernmental and supranational procedures on cooperation; for IR theorists, the debate involves the explanatory power of rationalist versus constructivist assumptions about how states define and pursue their national interests or preferences (Wendt, 1987; Dessler, 1989). ${ }^{3}$ Indeed, many scholars look to the EU as the prime example of how supposedly egoistic states can learn to create a sense of common purpose, whether as a 'multi-perspectival polity' or as a system of 'epistemic communities' covering numerous issues (Ruggie, 1993; Wendt, 1994; Mercer, 1995).

Arguments about the limits of rational choice approaches to European integration have thus prompted a number of investigations into decisionmaking in many EU policy domains. ${ }^{4}$ However, the constructivist literature also neglects to explain how collective goals are made to persist over time and thus influence future behavior - the processes and consequences of institutionalization (Florini, 1996; Katzenstein, 1996; Checkel, 1998). In this article, I use the example of EU foreign policy cooperation to show how rationalist and constructivist approaches to institutionalized cooperation actually complement each other. First, EU foreign policy represents a 'least likely' case not only in EU affairs but in international relations more generally. States are usually expected to defend their sovereignty and autonomy in foreign affairs with great vigor; evidence of both institutional development and policy adaptation concerning this sensitive domain might support the notion of socially driven cooperation. Second, foreign policy adaptation cannot be explained in terms of domestic demands, as some versions of rationalism (such as liberal intergovernmentalism; see Moravcsik, 1993, 1998) assume. Although there clearly has been a growth in public support for the general idea of EU foreign policy, ${ }^{5}$ issue-specific lobbying in this area (at the national or EU levels) is virtually non-existent compared to 
that which takes place in Community affairs, where transnational actors regularly participate in the rule-making process. Instead, those in charge of EU foreign policy have a fairly high degree of 'agency slack' compared to other EU policy domains, which should help facilitate the creation of shared understandings and policy goals.

Third, changes in the foreign policies of EU member states cannot be adequately explained in terms of 'functional spillover' as occurs in other EU socioeconomic policy areas, typically as a result of the growth in crossborder economic transactions. ${ }^{6}$ Although the EU has increasingly used economic tools for foreign policy ends, there are few if any direct economic benefits to EU foreign policy; in fact, growing ambitions in this area have the potential to seriously disrupt the economic activities of the EC. In addition, no other regional economic organization has such overt pretensions of creating a common foreign (and security) policy, thus economic interdependence alone, a prerequisite for functional spillover, cannot explain the EU's unique pursuit of this goal. Fourth, nor can changes in this area be explained primarily in terms of 'political spillover' processes, which involve the activities of supranational EC organizations. Although these organizations (chiefly the Commission) have been increasingly involved in foreign policy, they clearly do not exert the same decisive influence over policy outcomes and institutional development as in the EC's socioeconomic policy domains.

Moreover, although unanimity governs EU foreign policy decisions, ${ }^{7}$ policy outcomes have not always reflected 'lowest common denominator' positions, as studies of EU intergovernmental decision-making under unanimity often assume. ${ }^{8}$ Without some form of qualified majority voting (QMV), goes the argument, the EU's common position must conform to the preference of the member state(s) favoring the status quo, or the lowest degree of policy change. On any given foreign policy issue discussed in the $\mathrm{EU}$, often at least one EU state is tempted to use its veto to prevent a discussion from moving to a concrete foreign policy action. Yet this has not always been the case; in EU foreign policy, the preference-outliers often adapt their positions in favor of the common one rather than veto such decisions. ${ }^{9}$ Although vetoes have occurred, there has been far more cooperation under this system than we might otherwise expect given its intergovernmental, unanimous procedures. In addition, given the selfcontained nature of EPC/CFSP, which prohibits issue-linkages with EC affairs, and the taboo against voting in EPC/CFSP, EU states are able to avoid permanent cleavages and power blocs. Even the celebrated FrancoGerman relationship has not dominated EU foreign policy. ${ }^{10}$ Outside influences, particularly US policies, have also been cited as a general motivation for EU foreign policy cooperation (Nuttall, 1992) and it is clear 
that EPC/CFSP provides an outlet for the EU to express differences with America. However, the argument about US influence must be substantially qualified: although America has consistently called for greater defense burden-sharing in Europe, its attitude toward EPC/CFSP initiatives has varied from outright opposition to indifference to support (sometimes within the same presidential administration), and many US policies have the potential to divide as well as unite Europe (Pardalis, 1987; Peterson, 1996). Thus we cannot explain the pursuit of EPC/CFSP only or even primarily in terms of American pressures. Finally, the level of cooperation under these rules is even more remarkable when one considers that other cooperationinducing incentives, such as side-payments or issue-linkages, are actually discouraged in the making of EU foreign policy. Consensus-building is the general rule, and EU member states are not allowed to purchase agreement through bargaining. Thus, the puzzle here can be restated in this way how does the EU, alone among regional organizations, manage to cooperate in this sensitive policy area in the absence of political activism by domestic actors or NGOs, sustained leadership by the most powerful EU member states, consistent pressure from non-EU member states (chiefly the US), functional spillover from other EU policies, political spillover from EC organizations, supranational voting procedures like QMV and quid pro quo bargains between EU member states?

The rest of the article is organized as follows. In the first section, I explain how the expansion of European foreign policy cooperation involves aspects of both rationalist and constructivist theories. EU foreign policy cooperation was created by an intergovernmental bargain among EU states concerned about their own foreign policy interests, yet over time national policy experts and, to a much lesser extent, supranational EC actors began to play a far greater role in the process. As institutions provide the crucial link between these logics of interest-formation (rationalist and constructivist) and styles of decision-making (intergovernmental, transgovernmental and supranational), in the second section I examine institutional development more closely, focusing on how the EU foreign policy system, largely through socialization processes, produced its own rules to fill in the gaps left by the original intergovernmental bargain. The third and fourth sections present the empirical data of EU member state policy changes, using a combination of elite interviews ${ }^{11}$ and evidence from the growing literature on EU foreign policy. The third section focuses on the cumulative output of EU foreign policy (i.e. the expansion of collective actions); the fourth section provides three illustrations of specific areas where certain EU states reluctantly adapted their individual foreign policies in light of common goals despite the presence of rules allowing them to veto those policies. 


\section{Rationalism, Constructivism and Institutionalization}

If EU foreign policy cooperation is indeed 'less than supranational but more than intergovernmental' (Wessels, 1982: 15; Øhrgaard, 1997) then how does it function and, more importantly, to what extent does it actually influence the foreign policies of EU member states? I argue that although EU foreign policy was established along strict intergovernmental lines on the basis of a grand bargain, it has become far more institutionalized (i.e. rulegoverned) than its architects had intended or even expected. Although institutional causes and effects can vary in many ways, the rules of EU foreign policy in particular are more complex and varied than the simple QMV-unanimity dichotomy often stressed by those engaged in the supranational-intergovernmental debate. Moreover, this ongoing process of institutionalization, in turn, has had an almost insidious impact on the way EU states define and pursue their foreign policies.

This is not to say that EU states behave irrationally; on the contrary, they are quite rational in their pursuit of institutionalized cooperation to achieve joint gains. Indeed, the general path of institutionalization in this domain can be explained as a rational way for EU states to intensify their cooperation without delegating more authority to EC organizations (the supranational solution) or to the most powerful EU member states (the intergovernmental solution). What has changed is the way the goals of the EU as a collective have become part of the interest calculations of EU member states thanks to the unique institutional trajectory of EPC/CFSP. Rather than behave in terms of the narrowly defined instrumental rationality favored by realists (where policy positions stem from concerns about power and survival under anarchy) and liberal intergovernmentalists (where policy positions stem from the domestic concerns of EU heads of government), EU states have increasingly learned to define many, though certainly not all, of their foreign policy positions in terms of collectively determined values and goals. They then act on these collective positions in the form of common foreign policy statements and joint actions, and increasingly delegate these policies to EC organizations.

These changes can be conceived along a continuum, with egoistic instrumental rationality on one end and social rationality on the other. ${ }^{12}$ As March and Olsen (1989) put it, at one end a logic of consequences dominates; at the other a logic of appropriateness takes precedence. The key point here is that certain types of institutional mechanisms can help states move from one end of the continuum to the other, which then influences their propensity for cooperation (Allen and Wallace, 1982). In the case of EU foreign policy, the chief reason for this crucial change is that its institutional mechanisms have both pre-empted the formation of fixed 
national foreign policy preferences on an expanding number of issues and socialized its elite participants into articulating a common European policy on those issues. These processes are more consistent with the social constructivist view of foreign policy - rational decision-making here is defined in terms of conformity to the social norms of the group rather than satisfying egoistic instrumental utility. ${ }^{13}$ In this view, densely institutionalized social settings condition actors to rely on shared values, ideas or knowledge in making their decisions. Thus, national policy positions are not formed in a social vacuum; they are highly contingent on regular (that is, institutionalized) interactions with other states (Sandholtz, 1996). Where institutions are lacking or weak (as in the formative years of EPC), states resort to self-interested decision-making based on their unique foreign policy traditions. These changes in institutional form and policy substance are tightly linked - while instrumental rationality can explain the intergovernmental origins and initially limited scope of EPC (Schneider and Seybold, 1997), its expansion, output and impact on EU states require sensitivity to arguments based on constructivism's socially inspired rational action.

Socio-historical institutional theory provides the crucial link between these perspectives (Finnemore, 1996), particularly in terms of specifying how general systemic conditions conducive to socially constructed interests (chiefly interdependence and transnational linkages; see Wendt, 1994: 389-90) can lead to specific common policy goals and cooperative behaviors. Common interests or problems do not by themselves lead to common solutions; even if EU states recognize the general need to speak with a single voice they must still find and articulate that voice. This is especially problematic in complex decision-making situations where multiple solutions are possible. To explain how EU states are able to find that single voice, we need to appreciate the complex relationship between three general types of institutionalized EU foreign policy decision-making - intergovernmental, transgovernmental and supranational. Intergovernmentalism represents instrumental rationality - heads of government bargain among themselves in weakly institutionalized settings (periodic summits) to achieve gains that must be approved (tacitly or explicitly) by domestic constituents. At the other end, supranational decision-making involves policies where common interests are so intense (and usually involve the single European market) that EU governments have delegated their sovereignty over those policies to the organizations and procedures of the Community. Linking these styles of decision-making is the transgovernmental network created under the EPC system, where relevant officials were able to conduct an intense discourse about foreign policy issues away from the glare of intergovernmental 
summits before they agreed to delegate certain aspects of their cooperation to EC organizations and procedures.

To be sure, the ambiguity of foreign policy cooperation as an issue-area may be highly conducive to this discourse, where it can be difficult to apply a stark cost-benefit calculation at every decision point (Keohane, 1984; Snidal, 1991: 701). Unlike cooperation on economic issues, where institutions are often an instrumentally rational response to the incomplete contracting problem, foreign policy cooperation does not involve a clear end-point (such as tariff reductions) that can be easily measured among participating states. In fact, EU foreign policy cooperation, as opposed to economic (EC) or military/defense (NATO) cooperation, may be uniquely suited to constructivist arguments. It does not involve 'negative integration' (such as the removal of trade barriers) among EU states, but is clearly an example of 'positive integration' involving more abstract or symbolic goals (such as the protection of democracy or human rights). In this domain, preference-formation and perceptions of social standards are as important as if not more important than, strategic interaction. ${ }^{14}$ When we consider that the definition of an issue-area is itself often a subjective process, and that European foreign policy cooperation as an issue-area was never clearly articulated, the limitations of intergovernmental explanations of EPC/CFSP become even more salient.

The role of institutional mechanisms is intensified in such a setting, since arguments about the means or form of EU foreign policy cooperation are necessarily linked to discussions about the ends or substance of such cooperation. In fact, EPC was criticized early on because EU member states tended to debate its procedures as much or more than its substance (Allen and Wallace, 1977). Yet therein lies a virtue recognized by constructivists participants in EU foreign policy must be open-minded about potential solutions to both institutional questions and policy problems, and they must be willing to argue about appropriate behaviors while respecting opposing viewpoints. ${ }^{15}$ Indeed, as we shall see, the most fundamental principle of European foreign policy cooperation is that EU member states must avoid taking fixed positions on important foreign policy questions without prior consultation with their partners. ${ }^{16}$ This basic rule means we cannot regard such cooperation as an instrumentally rational process whereby EU states bring their predetermined, fixed positions to the table. Instead, the key catalyst in producing collective foreign policy decisions is the progressive institutionalization of communicative processes directed towards 'muddling through', 'learning by doing', and creative, incremental adaptation. ${ }^{17}$ As foreign policy cooperation grew into a legitimate EU policy domain, the dynamics of institutionalized cooperation within that domain changed as well. Three general propositions illustrate this transition from instrumental 
rationality based on predetermined national positions to socially constructed rationality based on collective positions.

First, the character of decision-making should change. When states hold conflicting policy views, instrumental rationality expects that cooperative agreements are most easily reached through specific bargains, often in the form of side-payments or issue-linkages. If bargaining is not allowed, and if states retain the right to veto any agreement (i.e. intergovernmentalism prevails and QMV is not permitted) the most likely result is a lowest common denominator solution. In EU foreign policy, the baseline for such a decision is generally the status quo - no common action, or common actions that require only a minimal degree of commitment (such as a declaration). Alternatively, the social constructivist view of rationality privileges debating over bargaining; the taking of final decisions, and most certainly the trading of favors, is not necessarily the primary objective. Instead, participants would argue about possible solutions based on their collective definition of the problem. This rhetorical communication (or discourse) would be increasingly articulated in terms of a common (European) interest rather than individual national interests. Through shared participatory roles, understandings and expectations, a new reference point, even vocabulary, would emerge. Actors may even begin to see each other as partners or colleagues, rather than negotiating opponents or players in a bargaining game. ${ }^{18}$ And in situations where states do come to the table with a preference for the status quo (no action), and a majority of their partners favor a more costly common action, the preference-outliers might be willing to adjust their positions (i.e. commit themselves to a more costly common action) without resorting to a bargaining game. The result would be an increasing number of 'median' positions, and even more high-cost actions, reflecting the will of the group as a whole, not lowest common denominator positions determined by the state(s) favoring the status quo. ${ }^{19}$

The second proposition concerns agenda-setting and leadership. In an intergovernmental setting governed by instrumental rationality, where states refuse to delegate to EC organizations, the largest, most powerful states often have the most impact. Power is generally defined in material terms; thus, in the case of the EU foreign policy cooperation France, Germany and the UK should have the most influence over outcomes. They might also be the least likely to adjust when their policy preference is not chosen. Where social rationality plays a role, however, power (if one can even apply the term) is defined in terms of arguments, language and ideas oriented around collective values. These 'resources' can be mobilized by any actor, particularly in a setting where all member states have an equal opportunity, and even an obligation, to lead the others. Therefore, leadership in the system 
might come from any legitimate actor (whether states or EC organizations) and not just those whose material power outweighs that of the rest.

The third proposition concerns change, in terms of both institutions and substantive policies. In the absence of powerful external or internal forces (such as a change in the global balance of power, or an internal institutional crisis) instrumental rationality expects a minimal amount of institutional change. As students of domestic institutions (chiefly bureaucracies) are well aware, reproduction and maintenance of the existing institution, even stagnation, are the norm. Similarly, policy change or expansion would not occur in the absence of compelling pressures (that is, the benefits must clearly outweigh the costs), such as the existence of an external security threat to the EU. Conversely, the social rationality of constructivism generally allows for far more dynamism, even in the absence of external or internal pressures, although it is difficult to predict the specific course of change. As institutions develop, however, logics of appropriateness and path-dependency begin to exert more influence, so that reforms are increasingly defined in terms of previous institutional elements (March and Olsen, 1989; Pierson, 1993). Still, while institutional change and the expansion of policies are expected, the distinct character of change will depend not only on the evolving discourse of existing participants but also on the inclusion of new actors in the system and an expansion or redefinition of common values, as happens with changes of government, rotation of presidencies or enlargements of the EU.

Since these processes are part of a continuum rather than dichotomous, we cannot isolate and operationalize the precise point where social rationality becomes more salient than instrumental rationality. And certainly there are still some issues that EU states are unwilling to submit to the EPC/CFSP process; we would not expect the EU to have a monopoly on all foreign policy decisions. However, since time is a key element in these propositions, we should at least be able to compare the performance of EU foreign policy at the time of its creation and in its current state, both in terms of its institutional elements and its cooperative output. These tasks are undertaken in the rest of this article.

\section{The Institutionalization of Policy Adaptation}

In this section I explain how EU foreign policy matured from a weak intergovernmental forum inspired by instrumental rationality into a more institutionalized policy-making system governed by social rationality. As this system has grown quite complex and is still evolving, I do not intend to describe and explain the function of every institutional element of EPC/ CFSP or the emerging European Security and Defence Policy. Instead I limit 
myself to three general processes in the institutional development of EU foreign policy that, taken together, helped to facilitate a gradual change in policy adaptation on certain foreign policy issues since 1970. These processes involve - (1) the creation and structure of the original intergovernmental forum of EPC; 2 ) the expansion of the transgovernmental EPC/CFSP communications network to support that forum; and (3) the emergence and codification of EU foreign policy rules governing $\mathrm{EU}$ member states and EU organizations such as the Commission.

\section{EPC and Intergovernmentalism}

EPC was based on the Luxembourg Report of 1970, a document prepared by the representatives of EU member state foreign ministers. Although they had been instructed by EU heads of government to 'study the best way of achieving progress in the matter of political unification, within the context of enlargement', ${ }^{20}$ the foreign ministers and their representatives merely created a vague forum for discussions about foreign policy. Yet this was no small success, as previous plans to cooperate in this area had failed spectacularly; one (the European Defence Community of the 1950s) because it was deemed too supranational and defense oriented; the other (the Fouchet plans of the 1960s) because they were too intergovernmental. EPC was a compromise between these visions - it was intergovernmental, yet it was located outside the institutions of the EC and thus would not 'contaminate' the Community with intergovernmental procedures. Nor would it involve security or defense issues.

This compromise was embedded in a much larger bargain - France finally agreed to allow the UK to join the EU in exchange for some form of foreign policy cooperation (which France hoped to lead) and for permanent funding of the Common Agricultural Policy. At this time, EPC was neither a legal treaty nor an EC institution; it was a 'gentleman's club' in which European diplomats could periodically socialize and engage in discreet discussions about foreign policy problems (Nuttall, 1992: Ch. 1). Decisions were made strictly by consensus, the Commission was only an invited observer to the discussions (Nuttall, 1996), and the European Parliament and the European Court of Justice were deliberately marginalized in EPC. Other difficult questions such as the relationship of EPC to EC policies, and the potential tools available to EPC, were deliberately (and wisely, one could argue) left unresolved. Thus, for egoistic states wishing to make a rational choice to cooperate informally and inexpensively (it required no financial support at the time), EPC exhibited all the requisite characteristics - it did not involve explicit or formal commitments; it was not ratified; and it could be changed or abolished at will (Lipson, 1991). 


\section{The Transgovernmental EPC Network}

The importance of these structured conversations became more evident when EPC ceased to be dominated by EU heads of government and their foreign ministers. Soon after the adoption of the Luxembourg Report, EPC was enhanced by the creation of a complex transgovernmental network of policy experts who helped to erode the monopoly over foreign policymaking held by the temporary EU governments who adopted decisions in the European Council and the EU Council of (Foreign) Ministers (i.e. the General Affairs Council). As it developed between 1970 and the present, this network involved an increasing number of regular meetings of EU foreign ministers and their political directors (i.e. the Political Committee), a group of European Correspondents to prepare the meetings, and regular meetings among EU diplomats in non-EU capitals and in international organizations and conferences (Jörgensen, 1997; Tonra, 2000).

These forums were increasingly supported by a number of transgovernmental working groups devoted to particular functional or geographic problems, where much of the joint analysis of problems and solutions took place. By the time of the Maastricht Treaty, the EU had over 20 permanent working groups who engaged in 'quasi-permanent multilateral negotiation' (de Schoutheete, 1980: 76-9) about specific foreign policy issues. ${ }^{21}$ From 1973, EPC also enjoyed its own dedicated encrypted telex network, the COREU (correspondance Europeène) system. ${ }^{22}$ With the Maastricht Treaty the network expanded to include new officials ('CFSP counselors') in the Committee of Permanent Representatives (i.e. ambassadors) to the EU (COREPER) and more representatives of other EC organizations such as the Commission and the Secretariat General of the Council of Ministers. ${ }^{23}$ Finally, the Amsterdam Treaty created a new position of 'High Representative' for the CFSP to give a stronger voice to the EU's foreign policy ambitions (in addition to the proliferation of 'special representatives' for particular issues). Thanks to this complex network of foreign policy experts,

styles of operating and communicating have been transformed. The COREU telex network, EPC working groups, joint declarations, joint reporting, even the beginnings of staff exchanges ... have moved the conduct of national foreign policy away from the old nation-state national sovereignty model towards a collective endeavor, a form of high-level networking. (Hill and Wallace, 1996: 6)

In other words, the EU foreign policy system — largely a decentralized but authoritative network of deliberative forums - began to develop its own culture of cooperation involving standards of behavior, shared understandings and a common language. Entrenched lower-level officials within 
EU member states, in Brussels, and in third countries and international organizations could discuss problems, prepare decisions and provide forward momentum to the system, even in the absence of strong leadership by the Commission. These activities are clearly in line with constructivist expectations concerning the importance of communication channels for redefining problems, interests and policy options. Such intensive deliberation within the EPC/CFSP working groups also encourages the formation of small epistemic communities of experts devoted to particular problems. As Müller and van Dassen suggest (1997: 68) in their analysis of EPC/CFSP efforts regarding non-proliferation (see below), national experts work together and

they hear and accept the same arguments repeatedly, twisted and turned from various national points of view; they use the same words and may even create their own words, abbreviations, meanings, and understandings. They may develop personal sympathies, and, not to be forgotten, is the fact that a common institutional memory is created.

Charles de Gaulle had another, slightly more pejorative, name for a similar process, 'copinage technocratique', whereby friendly, 'old-boy' networks among technical experts concerning policy problems threatened the sovereignty of EU member states. The case of EPC shows how such networks can evolve among diplomats in addition to technical experts. This deliberate, though subtle, institutionalization of the transgovernmental network, which created a new set of semi-permanent stakeholders, gave more dynamism and policy substance to a system that might otherwise have atrophied had it remained the exclusive, intergovernmental preserve of rotating EU foreign ministers.

\section{EU Foreign Policy Rules}

Despite such intensive communication, familiarity with another's point of view may not by itself lead to changes in behavior (Mercer, 1995: 249). To remedy this problem, EPC began to generate its own unique set of cooperative customs. Created and internalized by professional experts with similar status within this framework, they matured into rules, or shared standards of behavior, long before their codification in treaty form. The participants as well began to see themselves as colleagues in a shared enterprise rather than policy experts devoted to national goals. ${ }^{24}$ With this understanding, compliance based on coercion is less important than the fact that these rules have symbolic value - and not just in terms of instrumental utility - for those directly concerned: they represent the professional standards of a social peer group. In EPC, these norms became so important that steps were taken as early as 1977 to compile them into a collection, the 
coutumier ('custom'), ten years before the Single European Act gave them treaty status. Similarly, EU foreign policy declarations and other substantive policy texts were grouped into the recenil ('collection'). Both of these collections were transferred among officials as the six-month rotating EU presidency changed hands.

In general, the EU foreign policy system is oriented toward consensusbuilding, problem-solving and the creation of common understandings, interests or reference points, which then form the basis for common positions or joint actions. This is fundamentally different from the instrumentally rational, bargaining-based approach, whereby outcomes reflect nationally-determined self-interests. Of course, grand bargains have often taken place during major 'constitutional moments' of the EU (such as during intergovernmental conferences) where institutional reform is often a major item on the agenda. The Maastricht Treaty was one of the most prominent such institutional moments where EU states took advantage of historical circumstances (the unification of Germany and the end of the Cold War) to forge a new bargain - the linkage of political union (and the CFSP) to economic union within the new European Union framework. Yet such blatant reciprocity is explicitly discouraged in terms of specific EPC/CFSP policy decisions; instead, consensus-building and problem-solving are increasingly oriented around the EU as a collective entity and the use of persuasion, peer-pressure or (temporary) ostracism to encourage potential defectors to adopt the common view. ${ }^{25}$ This is especially effective when states are considered equal partners and all have an opportunity to contribute to the common good; it would be self-defeating for them to push their own national preferences on others. Although these processes often threaten to lead to deadlock, the institutional development of EPC/CFSP helped EU states avoid this problem while allowing them to keep foreign policy issues outside the framework of the Community for so long.

For example, in EPC/CFSP, consensus-building and problem-solving are deliberately encouraged by several rules. Together with the reports and treaties on which EU foreign policy is based, these norms comprise the acquis politique ${ }^{26}$ and accepting them became a condition of EU membership by the time of Greece's accession in 1981. As noted, EU member states adopted a general rule to consult with each other before adopting final positions of their own so that policies of their partners would not catch them by surprise. This rule was closely linked to the development of the transgovernmental communications network mentioned above - little progress toward cooperation could be made if states merely used the system to express rigid foreign policy positions to each other. ${ }^{27}$ By the mid-1970s, EU states were sending an average of 4800 COREU telexes a year regarding sensitive foreign policy issues $;^{28}$ this number grew to nearly 13,000 a year by 
the 1990s (Institut für Europäische Politik, 1995: 8). The practice became so habitual that a unique term - the 'coordination reflex' - was created to describe it. Although there have been a number of instances where some EU states attempted unilateral action before consultation, such behaviors are viewed as deviant by other EU states. Moreover, through these messages and other communication mechanisms (or the 'communauté d'information'), such a priori consultations help to define European foreign policy as an issue-area while also fostering the development of a communauté de vue on what constitutes 'European interests'. These consultations directly led to policy adaptation (a communauté d'action) on substantive issues, as we shall see (de Schoutheete, 1980: 49).

EPC/CFSP discussions are also confidential; states cannot use information shared during them to embarrass or blame other states. Similarly, EPC benefited from another rule - the notion of domaines réserves - that has nonetheless eroded over the years. Domaines réserves refer to subjects considered off-limits due to the objections of one or more EU states. These generally include unilateral problems within member states (such as separatist movements); bilateral problems between member states (such as Northern Ireland) and crises with military consequences affecting one or more partners (such as African civil wars; see Franck, 1983: 100-2). As a realist might expect, this rule occasionally prevented the discussion of many difficult security or defense issues. However, as EPC/CFSP developed and its ambitions grew, this rule became increasingly irrelevant, and we are able to observe a gradual expansion of the policy agenda to include many previously taboo subjects, such as terrorism. The importance of discourse in confining the domaines réserves is reflected in Simon Nuttall's observation (1992: 12-13) that EPC mainly operated by 'talking incessantly': officials simply pestered each other in hundreds of meetings and COREUs until a common view emerged which was understood to be morally if not legally binding upon all.

One final key set of rules involves the role of the rotating six-month EU presidency in foreign policy, which became more central as EPC/CFSP's main contact with outsiders. Holding the EU presidency is the first major test of a member state's commitment to the EU. The presidency reduces the importance of bilateral 'special relationships' in some cases, and allows smaller states to play a greater role in policy-making and brokering compromises than one might otherwise expect of a purely intergovernmental system. ${ }^{29}$ The presidency also encourages a healthy spirit of competition in the EU, while helping to establish a foundation of trust, which is elemental to problem-solving (Wallace and Edwards, 1976; O’Nuallain 1985; de Schoutheete, 1988; Kirchner, 1992). Further, each presidency publicly announces its goals for 'Europe,' and is thus closely 
watched by other EU states, which involves reputation, demonstration and socialization effects (Wallace, 1983). States cannot expect to use the presidency for their own ends if they wish to appear successful in the eyes of their EU partners; in this role they must take the lead in devising, articulating and representing the EU's common foreign policy position in a number of settings, bilateral and multilateral. Given the inherent secrecy of EPC/CFSP deliberations, the EU presidency is perhaps the most important forum where public shaming of a state can occur if it fails to manage this role well.

Complaints about not conforming to this body of general procedures have been rare (Wessels, 1982; also author interviews with EPC/CFSP participants). Together, these rules gave considerable substance to EPC, which had been established as a vague issue-area with few obligations or policy goals. These goals were not imposed by powerful EU states; they emerged through a constant process of consultation and deliberation - or discourse - primarily among professional lower-level diplomats (as opposed to temporary government ministers or transnational interest groups) in all EU states. Later, EPC established its own small secretariat to help administer its regular activities (da Costa Pereira, 1988), and it began to involve other EC organizations (chiefly the Commission) in order to make its decisions more consistent with EC activities. Consistency between EPC and the EC became a formal rule with the 1987 Single European Act, which allowed the Commission to help bridge the gap between these two forms of cooperation (particularly when economic sanctions were involved). Still, the activities of the Commission in EU foreign policy pale in comparison to its normal functions (initiating, implementing and monitoring EC legislation) in Community affairs. With the creation of the CFSP in the 1991 Maastricht Treaty, EPC was finally transformed into a formal policy process involving agenda-setting, decision-making, implementation, financing, democratic oversight and coherence with other EU policies and procedures (Tietje, 1997; Smith, 2001b, 2003). These reforms would have been difficult if not impossible without the 20 years of groundwork laid by EPC.

\section{Aggregate Measures of European Foreign Policy Adaptation}

EU foreign policy is now far more than an informal forum for discussions. As we have seen, it encourages EU member states to share information, formulate common understandings and create specific foreign policies based on those understandings. EU foreign policy has its own unique discourse coordination reflex, acquis politique, COREU, coutumier, recenil, domaines réserves, and so on. Yet to fully appreciate the effect of EU foreign policy cooperation on EU states, we need to measure its performance record in 
terms of substantive outcomes or collective behaviors. This section and the next one attempt to do just that. In this section I examine the aggregate output of EU foreign policy; in the next section I focus on three specific case studies to demonstrate the extent to which individual EU states (namely the preference-outliers) adapted their foreign policies in light of common EU standards.

The creation of EPC in 1970 provides us with a convenient benchmark against which we can measure cooperative outcomes. As with my discussion of institutional development, the goal here is to summarize general trends in cooperation over the past 30 years, not individual decisions or influences. In general, and as we might expect of such a weakly institutionalized forum (at first), EPC was relatively inward-looking and kept a very low profile during its first decade as its member states tried to establish practical procedures to achieve their ambitions. At the first EPC meetings in the early 1970s only a handful of issues were discussed, such as the Middle East and East-West relations. EPC at this time also took few concrete policy decisions beyond issuing the occasional declaration. However, this situation gradually changed as EPC became institutionalized in ways discussed above, and more positive results of EPC can be seen almost from the beginning. In particular, EPC/ CFSP's performance record can be measured in four ways:

1. Actions: an increase in the overall number of EPC/CFSP actions taken each year.

2. Functions: an expansion of the types of issues discussed in EPC/CFSP.

3. Instruments: an expansion of the policy tools used to meet the goals of EPC/CFSP.

4. Consistency: more linkages between the external policies of the EC and those formulated within EPC/CFSP.

First, the creation and strengthening of EPC clearly resulted in an expansion of collective foreign policy actions. According to Roy Ginsberg's comprehensive surveys of EU foreign policy activity, ${ }^{30}$ collective EU foreign policy actions gradually increased in number as EPC developed and was transformed into the CFSP. Prior to EPC, genuine multilateral European foreign policy cooperation (that is, cooperation involving all EU member states as opposed to just the larger ones) was very limited. While EU states could discuss defense policy in the NATO framework, they took only two notable multilateral foreign policy actions between the 1957 Rome Treaty and the creation of EPC in 1971 - the imposition of economic sanctions against Rhodesia (1965) and Greece (1967). Actions grew to slightly less than 20 during the first decade of EPC, then expanded to 50 during its second decade to well over 100 during the 1990s. Although EPC produced only a modest number of actions in the 1970s, we must keep in mind that during 
this time EPC was not especially directed toward conducting external actions, and there were no provisions for undertaking such actions within its institutional framework. ${ }^{31}$ The decade after the London Report (1981) particularly resulted in a significant expansion of EPC actions; this expansion was then dwarfed by the number of actions after the CFSP entered into effect in November 1993.

We should also note that these actions spanned a much greater range since 1970 to encompass policies and relationships in all corners of the globe. By the time of the Maastricht Treaty in 1991, virtually no geographic region was off-limits to EU foreign policy, a trend that was well in place before the end of the Cold War. Moreover, these new actions and topics are not necessarily important to the EU's largest states. Under the CFSP, all EU states (and the Commission) help set the EU's foreign policy agenda and together they have forged common positions on hundreds of issues.

Second, EPC expanded in terms of the number of functional issues with which it dealt. EU states discussed and voted on a wide variety of subjects at the UN, but in terms of external EPC actions on specific issues, member states limited themselves to discussions of a long-term nature, in order to ensure a common understanding of 'great international problems'. As with other aspects of EPC, however, its functional tasks were soon clarified in far more detail beyond this 'declaratory diplomacy'. In general, it became oriented toward the formulation of medium and long-term common positions on foreign policy matters. From there its tasks expanded to involve crisis response, as in Portugal, Cyprus, Afghanistan, the Falklands, and so on. ${ }^{32}$ EPC also became useful in drawn-out efforts to help resolve conflicts, as in the area of East-West relations, the Middle East and Central America. Following the transition to the CFSP in the 1990s, the EU began to involve itself in conflict prevention/democratization processes, as in the Central/ Eastern European states, the Mediterranean region, the former Soviet states, South Africa, Central America and elsewhere (for detailed case studies, see Holland, 1995; Smith, 1995; Mayhew, 1998; Smith, 1998; Spencer, 2001).

In a significant departure from the original EPC agenda, EU states also increasingly considered security issues and took several security-related actions. ${ }^{33}$ These include sanctions against Iran, Iraq, the Soviet Union, Argentina, Libya and Syria; embargoes on chemical weapons to Iran and Iraq; and emergency aid during the Persian Gulf War. Many of these actions were not the result of pressure from the US and most were not linked to Atlantic cooperation through NATO. In some cases these actions involved incidents which stimulated a common European response on their own; in others they emerged through the EU's own conception of its place in the world, as decided by its members. This 'self-styled' logic of cooperative 
Table 1

Establishment of major EPC/CFSP policy instruments

\begin{tabular}{|c|c|}
\hline Date & Policy Instrument \\
\hline 1970 & Declarations, démarches \\
\hline 1971 & Institutionalized coordination at the $\mathrm{UN}$ on various topics \\
\hline 1973 & Institutionalized consultations with allies outside the EU \\
\hline 1974 & Institutionalized regional political dialogues \\
\hline 1975 & Coordination at the CSCE; use of economic tools for EPC \\
\hline 1977 & Code of Conduct for EU firms in third states \\
\hline 1981 & Peace plans; endorsement of a military operation by some EU states \\
\hline 1982 & Use of an EC regulation for an EPC action \\
\hline 1984 & Weapons embargoes \\
\hline 1993 & $\begin{array}{l}\text { Common positions; joint actions; actions taken in conjunction with the } \\
\text { Western European Union }\end{array}$ \\
\hline 1998 & Common strategies \\
\hline 2000 & $\begin{array}{l}\text { Plans for an EU military/rapid reaction force and armaments } \\
\text { cooperation }\end{array}$ \\
\hline 2001 & Plans for coordinating civilian aspects of crisis management \\
\hline
\end{tabular}

action, as Ginsberg puts it, includes activity regarding issues as diverse as the control of terrorism and the support of democratization. Thus, like the expanded geographic terrain covered by EU foreign policy, virtually no external functionally defined problem, including military defense, is offlimits to discussion and action now.

Third, EPC also added to its repertoire of policy tools over the years. Table 1 illustrates the expansion of EPC/CFSP policy instruments: From its modest start in 1970 EPC developed the use of economic and financial aid, and economic and financial sanctions, which typically involved the EC to some extent. Policy instruments also expanded to include political dialogues and association agreements, embargoes on weapons and other products, anti-terrorism policies, peace plans and peacekeeping. By the 1990s, EU foreign policy, in the form of the CFSP, also was laying the groundwork for the use of police or military forces in certain areas, which now includes plans for a European rapid reaction force. The use of military force in the context of EU foreign policy had long been a taboo subject under EPC, and disagreements about this issue persist, but discussions on this subject are no longer out of place for EU states, even neutral ones.

Fourth, EU states gradually exhibited a greater willingness to use EC resources (rather than national contributions) for EPC/CFSP actions, a willingness that clearly had been absent during the 1970s. Many issues faced 
by the EC/EPC grew so linked that separating them into economic and political aspects for the mere purpose of satisfying two sets of procedures became extremely difficult. However, another reason for this change was the growth of the EU's aspiration to speak with a single voice in world politics and to assert its own unique identity, two goals announced as far back as the first decade of EPC. ${ }^{34}$ The taboo against involving EC competencies was almost completely eliminated with the CFSP, which established a procedure to regularly use EC resources to implement and finance CFSP joint actions. One can also detect a change in emphasis from 'reactive' foreign policy actions taken in response to particular events, to more proactive actions (even common strategies) that anticipate problems and devote resources to handling them (Holland, 1991; Schneider and Seybold, 1997). In this sense EU foreign policy has moved from negative integration (protecting the EU from the unilateral foreign policy actions of its member states) to positive integration (acting with a single purpose in world politics to serve common goals). This development, I argue, also reflects an institutionalized transition from the narrow instrumental rationality behind the creation of EPC to the more socially driven expression of a common interest reflected by constructivism.

To summarize, these activities reflect the tendency for all EU states to adapt their foreign policies on a wide range of issues in accordance with common EU norms. Even 'Euro-skeptics' like the UK have learned to value the EU foreign policy system; in fact, British foreign minister Douglas Hurd once wrote that it represented 'the biggest change of diplomatic method' in his country. Where the UK had previously shared diplomatic information primarily with the US, since EPC 'in some areas of diplomacy our policy is formed wholly within a European context, and in no area is the European influence completely absent. The flow of information between the (EU) foreign ministries is formidable' (Hurd, 1981: 383). According to another British insider,

The practice of EPC ... has made European foreign policy coordination second-nature. There's no doubt about it. I mean, when I joined the office in the late seventies, people did not give a toss for Europeans. You didn't think about speaking to 'Europe', you thought about speaking to French and Germans, and to close allies. You didn't speak about consulting 'colleagues'; it was basically national foreign policy first, and consulting European colleagues second. Now there is, I think, a 'reflex action' (toward consultation). ${ }^{35}$

This trend toward the 'Europeanization' of foreign policy among EU states is a direct result of the institutionalized socialization processes discussed in the previous section. Common foreign policies also encourage sympathetic activities in the domestic politics of EU member states. Although these are far too numerous to explore here, they generally involve joint reporting, the 
joint preparation of declarations or actions for ministers, the sharing of tasks, officials and facilities, and even the secondment of diplomats to another EU state's foreign ministry. ${ }^{36}$

Thus, EPC/CFSP has fundamentally changed the way EU states define and pursue their foreign policies. Evidence for increasing acceptance of EU foreign policy cooperation can be found in interviews, personal accounts (von der Gablentz, 1979; de Schoutheete de Tervarent, 1980; da FonsecaWollheim, 1981; Hurd, 1981, 1994; Nuttall, 1992; Crowe, 1993) and scholarly research (Wallace, 1982; Hill, 1983; de la Serre, 1988; Hill, 1996; White, 1999; Manners and Whitman, 2000). By the London Report of 1981, EU states publicly admitted that EPC had become 'a central element' in their foreign policies. The acquis politique is generally respected by all EU member states, and its acceptance is required of all prospective EU member states. As one analyst put it, the most 'striking fact' of EPC is that,

despite differences of nuance in the attitudes of the member states, the principle and procedures of EPC are now widely accepted. Such a development could not have been predicted given the resistance of certain partners to the ideas put forward in the Fouchet plans (of the early 1960s), and the misgivings expressed by the same countries about a form of inter-state cooperation which challenged the belief in supranational integration. (de la Serre, 1988: 195)

This voluntary sharing of sensitive information and the willingness to treat other diplomats as colleagues rather than foreign negotiators demonstrate the high degrees of social interaction and trust among these states. As Chris Hill and William Wallace note (1996: 1),

the image of rational policy-makers bargaining with each other within established regimes leaves too little room for this engrenage ('gearing' or 'lockin') effect. . . . Officials and foreign ministers who sit together on planes and round tables in Brussels or in each other's capitals begin to judge 'rationality' from within a different framework from what they began with.

\section{National Adaptation on Substantive EPC/CFSP Issues}

The EPC/CFSP mechanism clearly has produced numerous collective foreign policy actions among EU states. Moreover, I argue that many of these collective actions have in fact required EU states to adapt their own foreign policies in the absence of side-payments or issue-linkages. By 'policy adaptation' I mean either a change of an existing position or the creation of a new position on an unsettled policy problem thanks to a state's participation in the EPC/CFSP system. ${ }^{37}$ This system imposes specific foreign policy obligations on its member states, by virtue of EU membership in general and particularly when holding the EU presidency or representing 
the EU abroad. These responsibilities require that member states act as a point of access for outsiders and that they actively facilitate and articulate the 'European interest' in a variety of contexts. Lobbying by non-members also imposes on EU states 'the burden of having to have an opinion on matters in which (they) previously had not the slightest interest' (Lorenz, 1983: 160).

This requirement to create, adopt and defend collective foreign policy positions is felt across the EU. For example, the Nordic states are forced to consider problems in the Balkans and the Mediterranean; Spain and Portugal must become more sensitive to Central and Eastern Europe; and all EU states must help forge common positions on countries or regions (such as Africa, the Americas and Asia) far removed from their normal (that is, preEU) foreign policy agendas. As Trevor Salmon (1982: 217) has written of Ireland:

Community and EPC involvement have transformed Irish foreign policy. [EU membership] meant that (A) Ireland came into contact in a direct way with countries with whom its previous contact had been, at best, peripheral . . . and (B) it was faced with the need to have a view on issues which previously had only been of marginal significance to it, in other words the whole shape, form, and content of the psychological environment of Irish policymakers was transformed, notwithstanding the years at the UN.

The demands of EU membership and the habits of working together create and upgrade the idea of a common European interest, reflected as policy adaptation (engrenage or concertation). Methodologically, several analysts have used vote data from the UN General Assembly to show the extent to which national positions have converged since the creation of EPC. In general, most studies show a clear increase in unified voting among EU states after EPC was established in 1970. These trends generally stabilized in the 1980s, although later enlargements made uniform voting at the UN somewhat more of a challenge (Hurwitz, 1975, 1976; Lindemann, 1976; Foot, 1979; Lodge, 1989; Regelsberger, 1993). In addition to this general trend toward convergence, we should also note that on a number of votes EU cohesion was undermined by the dissenting behavior of only one state (often France and occasionally Greece), making it appear as if the EU was more divided than it really was. Non-uniform votes among EU states also may reflect tactical differences rather than basic disagreements over policy (Nuttall, 1992: 28).

To complement the vote data, it may be more instructive to take a closer look at the extent to which EPC/CFSP encouraged EU states to moderate their own views on specific issues. ${ }^{38}$ These examples can serve as plausibility probes to guide further research on the question of national adaptation to the EU. They involve the Middle East, actions against apartheid in South 
Africa and the issue of nuclear non-proliferation. The cases also represent different types of challenges for EU foreign policy - cooperation on principled issues like human rights (South Africa), finding a common position on a major regional conflict (Middle East) and cooperation on a sensitive security-related matter (non-proliferation).

In choosing the cases, I relied on several criteria based on the theoretical concerns motivating this article. First, since foreign policy adaptation requires time for actors to deliberate over a problem and its potential solutions, we must focus on long-term EPC/CFSP initiatives that span the 1970s to the 1990s. Second, the cases involve issues where several EU states clearly and publicly disagreed on the need for any collective action. In other words, opposing states had both reason and opportunity to unilaterally veto any collective decision given EPC/CFSP decision-making rules. Third, despite the disagreement and opportunity for a veto, all EU states must have approved and supported a higher-cost collective action (or set of actions) on the issue. ${ }^{39}$ In other words, the ultimate decision did not represent the lowest common denominator position (no action or a mere declaration), as intergovernmental theories might predict. Finally, in discussing the cases I focus primarily on the states who clearly preferred the status quo before succumbing to the influence of the 'Brussels consensus-building machine', as one official put it. ${ }^{40}$

\section{Palestine and the Euro-Arab Dialogue}

European attention to the Arab-Israeli conflict is one of the longest-running EU foreign policy initiatives, dating back to the first meetings of EPC in 1970 (Allen, 1978; Edwards, 1984). Here, the complexity of the issues was matched only by the vast dissimilarity in EU member state positions. During the Six Day War of June 1967 these different positions prevented the EU from even discussing the issue. Germany suggested doing so at a regular meeting of EU heads of government in Rome but was quickly rebuffed. France instead proposed a four-power summit (Britain, France, the US and the Soviet Union) to discuss a settlement to the conflict; this offer was rejected by the Americans. This failure on the part of the EU to even discuss their policies regarding such a major crisis eased the way for the drafting of the Luxembourg Report on EPC three years later. As German Chancellor Kiesinger recalled, 'I felt ashamed at the (1967) Rome summit. Just as the war was on the point of breaking, we could not even agree to talk about it' (Ifestos, 1987: 420).

The establishment of EPC quickly changed the situation and provided a stable forum for interested EU states, particularly France, to argue their views on this topic. At the very first EPC meeting in November 1970 the 
EU foreign ministers held a detailed exchange of positions on the Middle East and managed to agree to produce a joint paper on the subject. Toward this end the second EPC ministerial meeting in May 1971 devoted an entire day to problems such as refugees, the proposed demilitarized zones on the border between Israel and Egypt, the forces to be deployed there and the difficult question of Jerusalem (Allen, 1978). Despite a fundamental cleavage between EU member states, namely pro-Arab ones (such as France) and pro-Israeli ones (such as Denmark, Germany, the Netherlands and the UK), EPC approved a joint paper on these issues on 13 May 1971 (Nuttall, 1992: 68). This formed a foundation for sustained EU attention to the Middle East, institutionalized primarily through the 'Euro-Arab Dialogue' in 1974-5. Thanks to this forum, EU member state policies converged on a number of extremely difficult questions, such as the idea of a Palestinian home or state, Israel's 'right to exist' within secure borders and the right of the Palestine Liberation Organization (PLO) to participate in any negotiations. Most of these disagreements had been resolved by the time of the Venice Declaration of 30 June 1980, one of EPC's key policy statements. With agreement on these fundamental questions, the way was clear for a greater convergence of positions and higher profile actions after 1981.

For example, the Danes and the Germans traditionally supported Israel, but they gradually moved toward the EPC position, which was more sensitive to Arab views. This change was especially difficult and even embarrassing for Germany, given its desire to atone for its history with the Jewish people. ${ }^{41}$ Similarly, Ireland had few direct interests here before joining the EU, other than a general opposition to any colonial intervention (particularly by France and the UK). Yet the Irish learned to develop their positions toward the Middle East within the context of EPC. Moreover, the first Irish EU presidency, which occurred in 1975 during the first (and very difficult) sessions of the Euro-Arab Dialogue, was surprisingly active and effective in the Middle East. In what became known as the 'Dublin formula', Irish foreign minister Garret FitzGerald, in his own impressive display of 'shuttle diplomacy', helped set up working groups on both sides (EU and Arab) and proposed structuring the Dialogue on the basis of regional (rather than national) delegations to help avoid, temporarily, the question of recognizing the PLO (Allen, 1978; Keatinge, 1983: 143).

Luxembourg also had no firm position on the Middle East before the Euro-Arab Dialogue; however, by its 1980 presidency the country was acting in the region on behalf of the others in an effort (with its Italian and Dutch partners in the "Troika" ${ }^{42}$ ) to maintain the Euro-Arab Dialogue. Moreover, Luxembourg had no representation of its own in the Middle East, so EPC's Troika innovation was a considerable aid to the country (Lorenz, 1983: 162). Similarly, the Italians had been extremely reluctant to 
recognize the PLO due to domestic political divisions between pro-Arab and pro-Israeli factions of Italian political parties, yet the positions of successive Italian government(s) converged on the EU's position as a result of EPC deliberations, which led Italy to recognize the PLO (Bonvicini, 1983: 76-8). Yet of all EU member states, the Dutch probably adjusted the most on the Middle East. They showed strong support for Israel after the 1967 and 1973 wars, and the Netherlands alone among its EU partners suffered from an Arab oil boycott in November 1973. However, following EU discussions on the subject, the Dutch agreed to several major EPC Middle Eastern policy statements (November 1973, June 1977 and June 1980), including the radical idea of Palestinian rights. Former Dutch statements would not even mention the Palestinians, but EPC provided an incentive for the Dutch to move away from Israel (Pijpers, 1983: 176-7). Once these initial questions regarding Palestinian rights were solved, the EU was able to undertake a long-term program of assistance to the region, involving a series of trade and aid agreements, political dialogues and a series of CFSP joint actions to promote the peace process. ${ }^{43}$ These policies would have been difficult if not impossible without the groundwork laid in EPC.

\section{South Africa and the Anti-Apartheid Campaign}

The EU's anti-apartheid campaign in South Africa also dates back to the 1970 s and also involved fundamental disagreements among EU member states over the more general question of human rights. Here the smaller states often took the lead, to the frustration of the UK, France and, to a lesser extent, Germany. Ireland, along with Netherlands and Denmark (and occasionally Italy), formed the core of a progressive minority in support of moral principles such as justice, human rights and self-determination, beginning with their positions on Namibia and El Salvador. These states clearly demonstrated a willingness and ability to help adjust the focus of the three largest member states onto broader ethical concerns, instead of material interests alone. They also managed to back up these positions with concrete EPC/CFSP policy actions.

The EU's actions against apartheid provide a prominent example of this behavior. As usual, EPC's first statement on this issue was fairly weak; it merely condemned apartheid and stressed opposition to racial discrimination. However, in a series of increasingly bold statements, the EU stressed that the state of emergency in South Africa must be lifted, that all political prisoners must be freed and that the ban on political parties must be lifted. The Dutch in particular played a leading role here, and the campaign proved to be one of the EU's most notable foreign policy successes. Here the Dutch 
were joined by the other 'moralists' mentioned earlier, plus Spain after it joined the EU in $1986 .{ }^{44}$ The Dutch were partly responsible for EPC's first concrete act against apartheid, the 1977 'Code of Conduct for Community Companies with Interests in South Africa', which established numerous protections for the black workers of those firms. The Dutch also successfully argued that sanctions against the white minority government of that country would be meaningless unless implemented by all EU states (Pijpers, 1983: 175-6). Although France, Germany, and the UK opposed apartheid in principle, they also objected to stronger measures against South Africa whether by the UN or the EU. All three states profited from arms sales to the South African government (among other economic links), and would have suffered from any economic sanctions imposed by EPC. However, following the Code of Conduct, EPC deliberations gradually and very successfully convinced all EU states to increase the pressure on the white minority government. The UK in particular learned the value of EU foreign policy as a middle ground between protecting its considerable economic interests in South Africa and its desire to respond to anti-apartheid pressures from other members of the EU and the British Commonwealth (de la Serre, 1988: 202).

In a series of EPC/CFSP debates leading up to (and following) the collapse of the white majority government in South Africa, a core of EU states argued for higher cost collective foreign policy actions to undermine the apartheid system and pave the way for a democratic transition. These actions ranged from the Code of Conduct noted above to include support (diplomatic and economic) targeted at non-violent anti-apartheid groups and sanctions (diplomatic and economic) targeted at the white government and its military forces, both of which were increasingly implemented by the Commission rather than individual EU member states. Throughout these debates, the UK, Germany, Greece and Portugal repeatedly expressed initial opposition to such costly measures, primarily to maintain access to South African natural resources, yet all four states declined to exercise their right of veto and thus succumbed to the wishes of their EU partners (van Praag, 1982; Holland, 1988, 1995). Ultimately, the EU's efforts clearly linked a general common interest (protection of human rights) and a foreign policy position (opposition to apartheid) with clear behavioral standards involving EU governments and their firms in South Africa. Thus the anti-apartheid campaign was used as far more than a coordination instrument (unlike the Euro-Arab Dialogue) and it seamlessly changed into one of the first and most proactive joint foreign policy actions under the CFSP in 1993 support for South Africa's democratic transition (involving a delegation of 450 EU officials led by the Commission). 


\section{Nuclear Non-Proliferation}

A far more notable change of national approaches to EU foreign policy involved the addition of security issues to the EPC/CFSP agenda, which posed a difficulty for EU states who favored the role of NATO in this area (Denmark and the UK) and EU states who did not want the EU to have any role in this area due to fears about militarizing the EU (Belgium and the Netherlands) or due to their strict neutrality (Ireland under EPC, and later Austria, Finland and Sweden). Although the establishment of EPC involved a tacit bargain to exclude security and defense matters, this taboo began to erode beginning with the EU's critical involvement in the campaign for the Conference on Security and Cooperation in Europe (CSCE), now the Organization for Security and Cooperation in Europe (OSCE). This effort still represents one of the EU's most important foreign policy initiatives, and it paved the way for more intensive discussions of security issues despite the unease of some EU member states (Schneider, 1997).

European action in the area of nuclear non-proliferation especially reveals a close relationship between institutional development and policy adaptation. Here, the positions of EU states diverged widely and they could not even agree to consider the possibility of finding a common approach to the early negotiations on the Treaty on the Non-Proliferation of Nuclear Weapons (NPT) in 1967-8. Although all EU states generally accepted the reality of the US nuclear umbrella over Europe, the EU's participation in the NPT talks over the years was seriously complicated by the possession of nuclear weapons by the UK and France, Germany's general sensitivity to such weapons and the attitudes of neutral states in the EU. As a result, none of the original six EU states was able to adhere to the NPT when it entered into force in 1970. EU states further disagreed on several other issues regarding nuclear technology, such as safety in nuclear power plants, exports of nuclear materials and nuclear strategy and arms control. However, after only a few years of discussions in EPC, the dispute over the EU's internal non-proliferation policy was ended and the NPT was ratified by EU states (except France) in 1975 (Müller, 1992). The issue of external proliferation also led to heated disputes (chiefly between France and the Commission) about the EC's authority in this area, which resulted in a novel solution putting the entire issue under the control of an EPC working group, rather than the EC or the European Atomic Energy Community (Euratom). As Harald Müller notes, this act was a watershed in the evolution of EU foreign policy - first, it represented a major breach of the taboo against discussing security matters in EPC; second, the continuous discussion of the issue 'almost automatically led the group to discussions of an ever wider area connected to its core mandate; and socialized national bureaucrats to think 
about proliferation in terms of coordinated policy'; and third, since EPC was controlled by foreign ministries, they were able to actively enmesh themselves in national decision-making on non-proliferation policy, thus usurping the authority of other relevant national authorities (Müller, 1992: 195).

The change of attitude saw EPC's first statement on non-proliferation in 1983; a year later the EU adopted the 'London guidelines ${ }^{45}$ regarding nuclear exports to non-EU countries and established additional rules and restrictions concerning the transfers of nuclear materials within the EU. These involved definitions of such materials, certification standards for states wishing to transfer materials, ${ }^{46}$ and provisions for the review of such regulations in light of future changes in the international non-proliferation regime. The safeguards were especially onerous on the EU's major nuclear suppliers - France, Germany and (to a lesser extent) Belgium and Italy. France in particular was not yet willing to link the statement with the NPT, as other EU states (such as the Netherlands) preferred. In addition, Spain was persuaded to accede to the NPT in the context of that state's accession to the EU and Euratom, and France joined the NPT in 1991 (Müller, 1992: 198). Thus, it is not an exaggeration to say that discussions in EPC were directly responsible for changes of position in these states. The same held true for Sweden a decade later. Prior to joining the EU in 1995, the Swedes had been extremely critical of the NPT process as long as US nuclear weapons were stationed in NATO non-nuclear states, which in Sweden's view violated the distinction between nuclear weapons states and nonnuclear weapons states. Sweden expected to remain non-aligned on the issue of renewing the NPT; however, upon joining the EU the Swedes not only stopped criticizing the NPT (as it had several times before), they fully participated in the highly successful CFSP joint action involving the NPT renewal conference. These changes represent incrementally growing (policy) convergence, stimulated through institutional progress', and result from the 'co-influence of institutional structure and socialization processes' (Müller and van Dassen, 1997: 60-1, 69). And although EU security cooperation has yet to extend to military affairs, the EU's difficulties in the Balkans recently prompted major institutional changes in this area in the form of a new EU foreign policy chief, a policy planning and early warning unit, a rapid reaction military force, armaments cooperation and civilian crisis management plans. ${ }^{47}$

To summarize, I have shown that EPC/CFSP encouraged the EU's preference-outliers to moderate their foreign policy positions on several contentious issues. Although exogenous events (such as crises or policy failures) can stimulate a reconsideration of positions, they cannot explain why the positions of Western European states converge - (1) in the EU setting (as opposed to other possible forums); and (2) in terms of specific behavioral 
obligations involving goals, financing, implementation, etc. Explanations based on domestic politics are also indeterminate; even if EU governments felt such pressures, this cannot explain why all EU states converged at the same time on the same policy at various stages in the deliberations. In all cases, EU states were not able to find a common approach to the policy issue at hand until it was deliberately introduced into the EPC/CFSP system. Finally, the three most important EU states in this discussion (France, Germany and the UK) did not have changes of government during most the period under consideration (the 1980s); instead, the existing government changed its own view on an issue in line with their EU partners.

Moreover, the record shows, and EU foreign policy practitioners freely admit, that EPC/CFSP actively discourages unilateralism on the part of the larger EU states; provides regular leadership opportunities for smaller EU states (and the Commission); and encourages involvement in policy issues for EU states which previously had no interest in them. For all EU members, foreign policy cooperation requires a redefinition of previously isolated issues (functional or geographic) in regional, European-centered terms, combining both economic (EC) and political (EPC/CFSP) questions. With these efforts, the EU may be as close as ever to assuming the character of a 'pluralistic security community', as Karl Deutsch anticipated in $1957 . .^{48}$ One might even suggest that EU foreign policy represents the emergence of a collective identity (or polity) in world politics (Hopf, 1998; Whitman, 1998), one not forged by a historical or material conception of interest but by an institutionalized discourse about values and Europe's common future.

\section{Conclusion}

Explanations of international cooperation based on instrumental rationality, although highly insightful, cannot explain all sources and consequences of cooperation. While policy coordination is more likely with extended time horizons, the identification of cheaters, leadership by a powerful state, the existence of an external threat, or international bargaining within institutional structures, these processes assume the existence of national interests and expect that states will cooperate only to the extent that those interests can be achieved. In this article, I argued that interests (and the foreign policies representative of those interests) are also contingent on social interaction and discursive practices, so that states may find cooperative solutions even without hegemonic leadership or quid pro quo negotiations. For EU foreign policy, such detailed coordination could not have occurred on such a regular basis without the institutionalization of communicative action framed in the context of EPC/CFSP. Thus agency is as important as 
structural development, in the form of increasingly dense interactions among uniquely empowered, rule-bound professionals or colleagues.

I also attempted to isolate the most important institutional mechanisms involved in EU foreign policy and link them to specific manifestations of policy adaptation. I have shown that EU states habitually coordinate their foreign policies and take joint actions in the service of those policies. Despite occasional examples of division on individual policy issues, such as the use of military force against Iraq, these behaviors are now deeply embedded in the national practices of EU member states, both procedurally and substantively. Moreover, when EU states do act unilaterally (or without prior consultation) on key foreign policy issues they are immediately criticized as defectors by others inside and outside the $\mathrm{EU}$, which indicates the presence of a social rule. The lack of robust compliance mechanisms in EPC/CFSP does not undermine the validity of the general rule to cooperate on foreign policy whenever possible. A simple counterfactual proves my key point - is it conceivable that, without EPC/CFSP, EU member states would have spontaneously produced hundreds of principled declarations and instigated dozens of concrete foreign policy actions over the past 30 years on an expanding variety of subjects? Such intensive cooperation would not have occurred without the institution-building that took place in the EU in general and EPC/CFSP in particular.

There are, however, limits to the capacity of institutions to condition state behavior, and the EU will face serious challenges in the near future. The EU may already have reached the limits of a consensus-driven approach to the CFSP, particularly in light of its pursuit of defense or military cooperation. Until EU member states agree on the basic purpose for a common military force - as the European branch of NATO (the UK), as an independent EU force (France), or solely as a peacekeeping/humanitarian force (Germany and Sweden) - they will face serious difficulties when attempting to mount their own operations. The enlargement of the EU will only add to the difficulties in forging a consensus on the more serious problems of world politics, such as terrorism, organized crime, drugs and weapons of mass destruction. The aspirant EU member states in Central/Eastern Europe have already demonstrated their willingness to oppose some current EU member states on certain questions, such as the use of force against Iraq. It remains to be seen whether the EU's constitutional convention will manage to find an institutional means to reconcile such differences and promote joint action, although this goal is a key item on the agenda.

More research into this link between national preferences, institutionalized rules and policy coordination (not to mention policy effectiveness) may also shed light on the question of an emerging European identity or polity. The social construction of foreign policy ultimately requires a public space in 
which policy-relevant knowledge or ideas are made legitimate, motivate collective action and symbolize a common identity. At present, the CFSP is limited as a public space in two ways - it is still highly elitist, and there is wide variety in the shared knowledge among its practitioners depending on the issue at hand and the composition of the committee (i.e. intergovernmental, transgovernmental, supranational or a combination of these) involved in deliberating that issue. However, and typical of foreign policy, most reforms in the CFSP have focused on the elite practitioners rather than attempting to engage EU citizens or interest groups. This results in a basic detachment between the two, as Zielonka (1998) points out, and ultimately inhibits the creation of a true public space for foreign policy.

However, there is some evidence of an emerging public space involving the EU's external political identity. Since the Single European Act, public support for foreign and security policy cooperation at the European level has grown, even in 'Euro-skeptic' states like the UK. This should give CFSP officials even more leeway to consider future joint actions, assuming the basic goals can be agreed in light of the problems noted above. And the EU already has defined specific foreign policy principles, which often inform its actions and identity. These include,

... emphasizing diplomatic rather than coercive instruments, the centrality of mediation in conflict resolution, the importance of long-term economic solutions to political problems, and the need for indigenous peoples to determine their own fate - all of these in contradistinction to the norms of superpower politics. (Hill, 1983: 200)

More recent statements in the Maastricht, Amsterdam, and Nice Treaties have attempted to clarify the EU's basic purpose in world politics, and have expanded the range of policy tools to serve that purpose.

Thus, if a foreign policy identity can be manifested as shared language, understandings, procedures and collective foreign policy actions, then Europe does exhibit such an identity. Here there is the possibility of a true constructivist interpretation, by which EU states reconstitute themselves in line with common values and create a new collective identity in the process. ${ }^{49}$ National foreign policy rests in part on shared values and norms among individuals, preserved and developed by collective historical experiences and state institutions, but transferring some of these responsibilities to the EU has taken time due to the lack of a central authority powerful enough to assert its interests over those of national states. There is also no prominent external threat to act as a catalyst, and to the extent that EU member state governments cling to archaic notions of national sovereignty, this identity will be difficult to develop. Instead, and for the moment, this identity will have to come from within the EU itself, whereby elite officials 
attempt to 'create a collective memory based on shared myths' (Smith, 1992 ) in the manner of European state-building. One can only hope that such identity construction does not lead to the same destructive consequences as did previous efforts to create territorially bounded politicomilitary units (i.e. states), consequences which led to the construction of Europe in the first place.

\begin{abstract}
Notes
Earlier versions of this article were presented at meetings of the International Studies Association and the Council for European Studies. For advice and support on this project I am grateful to Russ Dalton, Roy Ginsberg, Patrick Morgan, Simon Nuttall, John Peterson, Mark Pollack, Wayne Sandholtz, Chris Hill, Wolfgang Wagner and the anonymous referees of the European Journal of International Relations. For financial support, I would also like to thank the Council for European Studies, the US Fulbright fellowship program, the University of California Institute on Global Conflict and Cooperation/MacArthur Foundation fellowship program and the Swedish Government Information Service. Finally, I am grateful to the EU officials who agreed to be interviewed for this project.
\end{abstract}

1. Although this article also covers the pre-Maastricht period, I generally favor the term EU; I use the term 'European Community (EC)' only when referring to the procedures, organizations and policies of that pillar.

2. For example, although the Organization of American States was founded in 1948 (and its roots extend back to the International Union of American Republics in 1890) it was not until 1991 that the OAS adopted Resolution 1080 , which set up procedures to react to threats to democracy in the western hemisphere. It has been invoked only four times. The Association of Southeast Asian Nations, founded in 1967, pledges to promote regional peace and stability, yet its institutional mechanisms for doing so mainly involve economic, social, technical, scientific and administrative issues. Cooperation within these fields is only sporadic at best.

3. In this article I focus on what Ted Hopf (1998) calls 'conventional constructivism', which generally accepts positivist methodologies in defending its truth claims. This is in opposition to the 'critical constructivism' derived from postmodern literary criticism, which denies any objective truth. For a similar constructivist critique of the CFSP, see Glarbo (1999).

4. Sandholtz (1996) provides several examples.

5. As Hill and Wallace (1996: 7) note, the success of EU foreign policy is due in part to its 'self-contained characteristics: the secrecy of discussions, in sharp contrasts to the leakiness of Community negotiations, the absence of domestic lobbies and entrenched interest groups'. Growth in support for EPC/CFSP is documented in Eichenberg (1997). Majorities in all EU states supported EU foreign policy cooperation by 1995 .

6. In fact, one of the founding fathers of functionalism, Ernst Haas (1961), explicitly excluded foreign and security cooperation from his theory, which 
focused on spillover in economic policy sectors. Alternatively, Schmitter (1969) and Ginsberg (1989) have suggested that a common foreign policy might be encouraged as outside actors make demands on the EU in response to its policies, yet they did not specify the mechanisms by which the EU would formulate such a foreign policy. Schmitter also notes that external pressure might actually lead member states to reject any foreign policy coordination or even maneuver against each other for special advantages.

7. The 1991 TEU did provide for limited qualified majority voting under the CFSP for certain decisions related to policy implementation, but any such use of QMV had to be approved by a unanimous vote. The 1997 Amsterdam Treaty reformed this process slightly, but unanimity remains the dominant practice.

8. For example, see Jupille (1999) and Meunier (2000).

9. As one participant observed, 'The system does not operate under the perpetual threat of veto' and officials make 'genuine efforts to reach a positive outcome' (Nuttall, 1992: 12).

10. In the words of Christopher Hill, alignments in EU foreign policy are usually 'issue-centered, informal, and shifting.' See Hill, 1983: 196. This pattern has continued.

11. Conducted by the author in 1995-6 and 2001 with roughly 60 officials familiar with or involved in EPC/CFSP from all $15 \mathrm{EU}$ member states and its major institutions.

12. This is a reconfiguration of the constructivist argument found in Wendt (1994). Although this implies a change in identity (and even the creation of 'community') among EU states, I cannot delve into that question here. My only concern is whether increasingly institutionalized social interactions change the foreign policies of EU member states.

13. As Wendt (1995: 72) notes, many constructivists actually share with realists the view that states are rational and wish to survive in an anarchic international system.

14. Thelen and Steinmo (1992: 9). For more detailed critiques of the preferenceformation issue, see Legro (1995: 5-8); Legro (1996); Finnemore (1996).

15. On the role of argumentation in constructivism, see Risse (2000), and Schimmelfennig (2001).

16. EC Foreign Ministers 1973, Part II, Section 11; Single European Act, Title III, Article 30.2(b); Maastricht Treaty on European Union, Article J.2; Amsterdam Treaty, Articles 12 and 16.

17. Lindblom (1959). For more recent discussions, see March and Olsen (1989); and Bendor (1995).

18. As Mercer (1995: 250) puts it, 'The European Union does not imply a transcending of egoistic incentives but a more expansive definition of one's ingroup.'

19. Of course, the median point of view might actually favor the status quo (no or minimal joint action), in which case the EU does nothing or only issues a joint declaration. Or all EU states might prefer a higher cost joint action, in which case there is little need for debate. Such decisions do occur but they are 
theoretically and empirically uninteresting. I am primarily concerned with situations where only some EU member states prefer a greater degree of cooperation (i.e. a more costly action) but still manage to convince their partners to support such a policy.

20. Unless otherwise noted, quotes from summits, EPC reports and documents come from the documents collection European Political Cooperation, 5th edn (Bonn: Press and Information Service of the Federal Republic of Germany, 1988). The Hague Summit quotes are on p. 14.

21. A list of these groups is found in Regelsberger (1993: 273-4).

22. These mechanisms are set down in EC Foreign Ministers (1973). For an extended analysis, see Smith (2003: Ch. 4).

23. CFSP counselors meet as a group on a regular basis to tie together the legal, technical, economic, and political strands of CFSP decisions. 'Creation $d u$ Groupe de conseillers PESC, internal COREPER document, 26 July 1994; 'Recommendations of the Political Committee to the General Affairs Council', internal Council document, 18 July 1994. Also author interviews with COREPER and Council of Ministers officials, Brussels, February-April 1996. For more on the evolving role of the Council in the CFSP, see Galloway (1995).

24. This attitude was confirmed in numerous interviews by the author with EPC/ CFSP officials in all $15 \mathrm{EU}$ member states. Many participants also share common career patterns, which probably contributes to the socialization process (Hill and Wallace, 1979; Manners and Whitman, 2000; Smith, 2000).

25. Based on numerous interviews by the author with EPC and CFSP officials, Brussels, 1995-6.

26. Note the similarity to the term 'acquis communautaire', used to describe the large body of EC procedures and legislation.

27. As former British Foreign Secretary Douglas Hurd once observed (1981: 389), 'Perhaps one reason why these (failed) unilateral efforts now usually come to nothing is precisely that they are unilateral.'

28. This is the more conservative estimate from Wessels (1982: 2). Others put the figure at 8000 COREUs per year by the early 1980s.

29. Tonra (2001), provides a detailed examination of the small states and the CFSP.

30. According to Ginsberg's criteria (1989, 1991), which I revised here, such foreign policy actions must be - (1) undertaken on behalf of all EU states toward non-members, international bodies or global events or issues; (2) oriented toward a specific goal; (3) made operational with physical activity, such as financing or diplomacy; and (4) undertaken in the context of EPC/CFSP discussions (although the EC can also be involved).

31. Also note that European foreign policy cooperation was primarily expressed in terms of diplomatic démarches and joint declarations during the 1970s. Data for démarches do not exist, but joint declarations made each year expanded during the life of EPC, ranging from only a few in 1975 to 52 in 1985 to well over 100 
per year in 1995 (Regelsberger, 1993: 278; and the Official Journal, various years).

32. Hill (1992). The Falklands case is especially illuminating; see Stavridis and Hill (1996).

33. Defined as 'mutual changes in interstate behavior among EU members in order to undertake actions in which the EU deals as a unit with a question that affects its own physical security, the security of a closely related state or group of states, or the security of the international system' (Ginsberg, 1989: 57).

34. See the 'Document on the European Identity published by the Nine Foreign Ministers' (Copenhagen, 14 December 1973). These goals (collective action in world politics and asserting European identity) have been reaffirmed in all EU treaties since then.

35. Author's interview with a British foreign ministry official, London, November 1995.

36. In the case of EPC/CFSP, more permanent domestic changes include elite socialization processes, bureaucratic reforms to cope with the workload, constitutional reinterpretations or modifications, and growth in public support of EU foreign policy cooperation (Hill, 1983, 1996; Tonra, 1997; Smith, 2000, 200la).

37. Note that 'policy adaptation' (or cooperation, the focus of this article) must be distinguished from 'policy effectiveness' (or performance). States can still be considered cooperative even if some of their common policies are not effective.

38. Note that compliance with such collective decisions is not at issue here, since nearly all of the actions of concern in this article (proactive, high-cost actions) are now implemented by the EC. Thus my focus is on the initial decision among EU governments to undertake the policy.

39. Although these cases are presented as decisions where EU members simply had to choose between the status quo and a common position, EU foreign policy in practice obviously involves a wider range of choice than blatant unilateralism or a single unified foreign policy. Further, these choices are not mutually exclusive (Pfetsch, 1994). Still, the basic point is that EPC/CFSP provides an increasingly relevant frame of reference or convergence point for making foreign policy, helping EU states to undertake joint actions on an issue.

40. Author's interview with a CFSP counselor, Brussels, March 1996.

41. As Lisbeth Aggestam (2000: 70) notes, 'Given the special relationship and reconciliation that Germany has developed with Israel after the Holocaust, this was a remarkable reorientation of policy not conceivable outside the EPC framework.'

42. Consisting of the immediate past, current and immediate following holder of the six-month rotating EU presidency. The Troika was created to improve continuity across presidencies.

43. The Euro-Arab Dialogue is now effectively embedded in a broader EU strategy for the Mediterranean region, the Euro-Mediterranean Partnership Initiative. See Ginsberg (1989: chap. 5); and Gomez (1998). 
44. On Spain, see Barbé (1996); on Portugal, see de Vasconcelos (1996).

45. Negotiated between 1974 and 1977 by the major nuclear suppliers.

46. In particular, EU states were required to specify: the ultimate destination of nuclear materials, the delivery timetable, the use timetable, the form in which delivery will take place, and the use of such material (i.e., fueling, processing, research and development, or energy generation).

47. On the lessons of the Balkans, see Edwards (1997); Kintis (1997); Piana (2002).

48. Such a community would involve mutual trust, common values, predictable behavior, and intensified communication among member states, all of which generally apply to the EU. See Deutsch (1957).

49. Or as Dave Allen (1996: 288) puts it, the 'European rescue of national foreign policy.'

\section{References}

Aggestam, Lisbeth (2000) 'Germany', in Ian Manners and Richard G. Whitman (eds) The Foreign Policies of European Union Member States, pp. 64-83. Manchester: Manchester University Press.

Allen, David (1978) 'The Euro-Arab Dialogue', Journal of Common Market Studies 16(4): 323-42.

Allen, David (1996) 'Conclusions: The European Rescue of National Foreign Policy', in Christopher Hill (ed.) The Actors in European Foreign Policy, pp. 288-304. London: Routledge.

Allen, David and William Wallace (1977) 'Political Cooperation: Procedure as Substitute for Policy', in Helen Wallace, William Wallace and Carole Webb (eds) Policy Making in the European Communities, pp. 227-47. London: John Wiley and Sons.

Allen, David and William Wallace (1982) 'European Political Cooperation: The Historical and Contemporary Background', in David Allen, Reinhardt Rummel and Wolfgang Wessels (eds) European Political Cooperation: Towards a Foreign Policy for Western Europe, pp. 21-32. London: Butterworths.

Barbé, Esther (1996) 'Spain: The Uses of Foreign Policy Cooperation', in Christopher Hill (ed.) The Actors in Europe's Foreign Policy, pp. 108-29. London: Routledge.

Bendor, Jonathan (1995) 'A Model of Muddling Through', American Political Science Review 89(4): 819-40.

Bonvicini, Gianni (1983) 'Italy: An Integrationist Perspective', in Christopher Hill (ed.) National Foreign Policies and European Political Cooperation, pp. 71-82. London: George Allen \& Unwin.

Checkel, Jeffrey T. (1998) 'The Constructivist Turn in International Relations Theory', World Politics 50(2): 324-48.

Commission of the European Communities (1995) Commission Report on the Functioning of the Treaty on European Union. Luxembourg: Office of Official Publications of the EC. 
Crowe, Brian L. (1993) 'Foreign Policy-Making: Reflections of a Practitioner', Government and Opposition 28(2): 174-89.

da Costa Pereira, Pedro Sanchez (1988) 'The Use of a Secretariat', in Alfred Pijpers, Elfriede Regelsberger and Wolfgang Wessels (eds) European Political Cooperation in the 1980s: A Common Foreign Policy for Western Europe? Dordrecht: Martinus Nijhoff Publishers.

da Fonseca-Wollheim, Hermann (1981) Ten Years of European Political Cooperation. Brussels: Commission of the European Communities.

de la Serre, Françoise (1988) 'The Scope of National Adaptation to EPC', in Alfred Pijpers, Elfriede Regelsberger and Wolfgang Wessels (eds) European Political Cooperation in the 1980s: A Common Foreign Policy for Western Europe?, pp. 194-210. Dordrecht: Martinus Nijhoff Publishers.

de Schoutheete de Tervarent, Philippe (1980) La Coopération Politique Européenne. Brussels: F. Nathan Editions Labor.

de Schoutheete de Tervarent, Philippe (1988) 'The Presidency and the Management of Political Cooperation', in Alfred Pijpers, Elfriede Regelsberger and Wolfgang Wessels (eds) European Political Cooperation in the 1980s: A Common Foreign Policy for Western Europe?, pp. 71-84. Dordrecht: Martinus Nijhoff Publishers.

Dessler, David (1989) 'What's at Stake in the Agent-Structure Debate?', International Organization 43(3): 441-73.

Deutsch, Karl (1957) Political Community in the North Atlantic Area. Princeton: Princeton University Press.

de Vasconcelos, Álvaro (1996) 'Portugal: Pressing for an Open Europe', in Christopher Hill (ed) The Actors in Europe's Foreign Policy, pp. 268-87. London: Routledge.

EC Foreign Ministers (1973) Second Report of the Foreign Ministers to the Heads of State and Government of the Member States of the European Community of 23 July 1973 (Copenhagen Report).

Edwards, Geoffrey (1984) 'Europe and the Falklands Islands Crisis, 1982', Journal of Common Market Studies 22(4): 295-313.

Edwards, Geoffrey (1997) 'The Potential and Limits of the CFSP: The Yugoslav Example', in Elfriede Regelsberger, Philippe de Schoutheete de Tervarent and Wolfgang Wessels (eds) Foreign Policy of the European Union: From EPC to CFSP and Beyond. Boulder, CO: Lynne Rienner.

Eichenberg, Richard C. (1997) 'Does Europe Want a Common Security Policy (Anymore than it Ever Did?)', paper presented at the annual meeting of the International Studies Association, Toronto, Canada.

Finnemore, Martha (1996) National Interests in International Society. Ithaca, NY: Cornell University Press.

Florini, Ann (1996) 'The Evolution of International Norms', International Studies Quarterly 40(3): 363-89.

Foot, Rosemary (1979) 'The European Community's Voting Behavior at the United Nations General Assembly', Journal of Common Market Studies 17(4): 350-60.

Franck, Christian (1983) 'Belgium: Committed Multilateralism', in Christopher Hill 
(ed.) National Foreign Policies and European Political Cooperation, pp. 85-105. London: George Allen \& Unwin.

Galloway, David (1995) 'Common Foreign and Security Policy: Intergovernmentalism Donning the Mantle of the Community Method', in Martin Westlake (ed.) The Council of the European Union. London: Cartermill Publishing.

Ginsberg, Roy H. (1989) Foreign Policy Actions of the European Community: The Politics of Scale. Boulder, CO: Lynne Rienner.

Ginsberg, Roy H. (1991) 'European Community Foreign Policy Actions in the 1980s', paper presented at the Second Biennial International Conference of the European Community Studies Association, May, Washington, DC.

Ginsberg, Roy H. (2001) The European Union in International Politics: Baptism by Fire. Lanham, MD: Rowman \& Littlefield.

Glarbo, Kenneth (1999) 'Wide-awake Diplomacy: Reconstructing the Common Foreign and Security Policy of the European Union', Journal of European Public Policy 6(4): 634-51.

Gomez, Ricardo (1998) 'The EU's Mediterranean Policy: Common Foreign Policy by the Back Door?', in John Peterson and Helene Sjursen (eds) A Common Foreign Policy for Europe? Competing Visions of the CFSP, pp. 133-151. London: Routledge.

Gordon, Philip H. (1997-98) 'Europe's Uncommon Foreign Policy', International Security 22(3): 74-100.

Haagerup, Niels Jorgen and Christian Thune (1983) 'Denmark: The European Pragmatist', in Christopher Hill (ed.) National Foreign Policies and European Political Cooperation, pp. 106-20. London: George Allen \& Unwin.

Haas, Ernst B. (1961) 'International Integration: The European and the Universal Process', International Organization 15(3): 366-92.

Hill, Christopher (1983) 'National Interests - The Insuperable Obstacles?', in Christopher Hill (ed.) National Foreign Policies and European Political Cooperation, pp. 185-202. London: George Allen \& Unwin.

Hill, Christopher (1992) 'EPC's Performance in Crises', in Reinhardt Rummel (ed.) Toward Political Union: Planning a Common Foreign and Security Policy in the European Community, pp. 135-46. Boulder, CO: Westview Press.

Hill, Christopher (1996) The Actors in Europe's Foreign Policy. London: Routledge.

Hill, Christopher and William Wallace (1979) 'Diplomatic Trends in the European Community', International Affairs 55(1): 47-66.

Hill, Christopher and William Wallace (1996) 'Introduction: Actors and Actions', in Christopher Hill (ed.) The Actors in Europe's Foreign Policy, pp. 1-16. London: Routledge.

Hoffman, Stanley (2000) 'Towards a Common European Foreign and Security Policy?', Journal of Common Market Studies 38(2): 189-98.

Holland, Martin (1988) The European Community and South Africa: European Political Cooperation Under Strain. London: Pinter Publishers. 
Holland, Martin (1991) 'Sanctions as an EPC instrument', in Martin Holland (ed.) The Future of European Political Cooperation: Essays on Theory and Practice, pp. 180-98. London: Macmillan.

Holland, Martin (1995) European Union Foreign Policy: From EPC to CFSP Joint Action and South Africa. Basingstoke: Macmillan.

Hopf, Ted (1998) 'The Promise of Constructivism in International Relations Theory', International Security 23(1): 171-200.

Hurd, Douglas (1981) 'Political Cooperation', International Affairs 57(3): 383-93.

Hurd, Douglas (1994) 'Developing the Common Foreign and Security Policy', International Affairs 70(3): 421-28.

Hurwitz, Leon (1975) 'The EEC in the United Nations: The Voting Behavior of Eight Countries, 1948-1973', Journal of Common Market Studies 13(3): 224-43.

Hurwitz, Leon (1976) 'The EEC and Decolonization: The Voting Behavior of the Nine in the UN General Assembly', Political Studies 24(4): 435-47.

Ifestos, Panayiotis (1987) European Political Cooperation: Towards a Framework of Supranational Diplomacy? Aldershot: Avebury.

Institut für Europäische Politik (1995) CFSP Forum l (Bonn).

Jörgensen, Knud Erik (1997) 'PoCo: The Diplomatic Republic of Europe', in Knud Erik Jörgensen (ed.) Reflective Approaches to European Governance, pp. 128-45. Basingstoke: Macmillan.

Jupille, Joseph (1999) 'The European Union and International Outcomes', International Organization 53(2): 409-25.

Katzenstein, Peter (ed.) (1996) The Culture of National Security: Norms and Identity in World Politics. New York: Columbia University Press.

Keatinge, Patrick (1983) 'Ireland: Neutrality inside EPC', in Christopher Hill (ed.) National Foreign Policies and European Political Cooperation, pp. 137-52. London: George Allen \& Unwin.

Keohane, Robert O. (1984) After Hegemony: Cooperation and Discord in the World Political Economy. Princeton: Princeton University Press.

Kintis, Andreas G. (1997) 'The EU's Foreign Policy and the War in Former Yugoslavia', in Martin Holland (ed.) Common Foreign and Security Policy: The Record and Reforms. London: Pinter Publishers.

Kirchner, Emil Joseph (1992) Decision-making in the European Community: The Council Presidency and European Integration. Manchester: Manchester University Press.

Legro, Jeffrey W. (1995) Cooperation Under Fire: Anglo-German Restraint During World War II. Ithaca: Cornell University Press.

Legro, Jeffrey W. (1996) 'Culture and Preferences in the International Cooperation Two-Step', American Political Science Review 90(1): 118-37.

Lindblom, Charles E. (1959) 'The Science of "Muddling Through", Public Administration Review 19: 79-88.

Lindemann, Beate (1976) 'Europe and the Third World: The Nine at the United Nations', The World Today 33(7): 260-69. 
Lipson, Charles (1991) 'Why Are Some International Agreements Informal?', International Organization 45(4): 495-538.

Lodge, Juliet (1989) 'European Political Cooperation: Towards the 1990s', in Juliet Lodge (ed.) The European Community and the Challenge of the Future, pp. 223-40. New York: St. Martin's Press.

Lorenz, Pierre-Louis (1983) 'Luxembourg: The Upgrading of Foreign Policy', in Christopher Hill (ed.) National Foreign Policies and European Political Cooperation, pp. 153-65. London: George Allen \& Unwin.

Manners, Ian and Richard G. Whitman (eds) (2000) The Foreign Policies of European Union Member States. Manchester: Manchester University Press.

March, James G. and Johan P. Olsen (1989) Rediscovering Institutions: The Organizational Basis of Politics. New York: Free Press.

Mayhew, Alan (1998) Recreating Europe: The European Union's Policy Towards Central and Eastern Europe. Cambridge: Cambridge University Press.

Mearsheimer, John J. (1994/95) 'The False Promise of International Institutions', International Security 19(3): 5-49.

Mercer, Jonathan (1995) 'Anarchy and Identity', International Organization 49(2): 229-52.

Meunier, Sophie (2000) 'What Single Voice? European Institutions and EU-U.S. Trade Negotiations', International Organization 54(1): 103-35.

Moravcsik, Andrew (1993) 'Preferences and Power in the European Community: A Liberal Intergovernmentalist Approach', Journal of Common Market Studies 31(4): 473-524.

Moravcsik, Andrew (1998) The Choice for Europe: Social Purpose and State Power from Messina to Maastricht. Ithaca, NY: Cornell University Press.

Müller, Harald (1992) 'West European Cooperation on Nuclear Proliferation', in Reinhardt Rummel (ed.) Toward Political Union: Planning a Common Foreign and Security Policy in the European Community, pp. 187-207. Boulder, CO: Westview.

Müller, Harald and Lars van Dassen (1997) 'From Cacophony to Joint Action: Successes and Shortcomings of the European Nuclear Non-Proliferation Policy', in Martin Holland (ed.) Common Foreign and Security Policy: The Record and Reforms, pp. 52-72. London: Pinter Publishers.

Nuttall, Simon (1992) European Political Cooperation. Oxford: Clarendon Press.

Nuttall, Simon (1996) 'The Commission: The Struggle for Legitimacy', in Christopher Hill (ed.) The Actors in Europe's Foreign Policy, pp. 130-47. London: Routledge.

Øhrgaard, Jakob C. (1997) "“Less than Supranational, More than Intergovernmental": European Political Cooperation and the Dynamics of Intergovernmental Integration', Millenium: Journal of International Studies 26(1): $1-29$.

O’Nuallain, Colm (ed.) (1985) The Presidency of the European Council of Ministers. London: Croom Helm.

Pardalis, Anastasia (1987) 'European Political Cooperation and the United States', Journal of Common Market Studies 25(2): 271-94. 
Peterson, John (1996) Europe and America: The Prospects for Partnership. London: Routledge.

Pfetsch, Frank (1994) 'Tensions in Sovereignty: Foreign Policies of EC Members Compared', in Walter Carlsnaes and Steve Smith (eds) European Foreign Policy: The EC and Changing Perspectives in Europe, pp. 120-37. London: Sage.

Piana, Claire (2002) 'The EU's Decision-Making Process in the Common Foreign and Security Policy: The Case of the Former Yugoslav Republic of Macedonia', European Foreign Affairs Review 7(2): 209-226.

Pierson, Paul (1993) 'When Effect Becomes Cause: Policy Feedback and Political Change', World Politics 45(4): 595-628.

Pijpers, Alfred (1983) 'The Netherlands: How to Keep the Spirit of Fouchet in the Bottle', in Christopher Hill (ed.) National Foreign Policies and European Political Cooperation, pp. 166-81. London: George Allen \& Unwin.

Regelsberger, Elfriede (1993) 'European Political Cooperation', in Jonathan Story (ed.) The New Europe: Politics, Government, and Economy since 1945, pp. 270-91. Oxford: Blackwell.

Risse, Thomas (2000) “"Let's Argue!” Communicative Action in World Politics', International Organization 54(1): 1-39.

Ruggie, John Gerard (1993) 'Territoriality and Beyond: Problematizing Modernity in International Relations', International Organization 47(1): 139-74.

Salmon, Trevor C. (1982) 'Ireland: A Neutral in the Community?', Journal of Common Market Studies 20(3): 205-27.

Sandholtz, Wayne (1996) 'Membership Matters: Limits to the Functional Approach to European Institutions', Journal of Common Market Studies 34(3): 403-29.

Scheich, Manfred (1992) 'View from Austria: Preparing for Membership', in Reinhardt Rummel (ed.), Toward Political Union: Planning a Common Foreign and Security Policy in the European Community, pp. 239-42. Boulder, CO: Westview Press.

Schimmelfennig, Frank (2001) 'The Community Trap: Liberal Norms, Rhetorical Action and the Eastern Enlargement of the European Union', International Organization 55: 47-80.

Schmitter, Philippe C. (1969) 'Three Neo-Functional Hypotheses About International Integration', International Organization 23(1): 161-6.

Schneider, Gerald and Claudia Seybold (1997) 'Twelve Tongues, One Voice: An Evaluation of European Political Cooperation', European Journal of Political Research 31(3): 367-96.

Schneider, Heinrich (1997) 'The Twelve/Fifteen's Conference Diplomacy: Has the CSCE/OSCE Remained a Successful Platform?', in Elfriede Regelsberger, Philippe de Schoutheete de Tervarent and Wolfgang Wessels (eds) Foreign Policy of the European Union: From EPC to CFSP and Beyond, pp. 237-61. Boulder, CO: Lynne Rienner.

Smith, Anthony D. (1992) 'National Identity and the Idea of European Unity', International Affairs 68(1): 55-76.

Smith, Hazel (1995) European Foreign Policy and Central America. New York: St. Martin's Press. 
Smith, Karen (1998) The Making of EU Foreign Policy: The Case of Eastern Europe. New York: St. Martin's Press.

Smith, Michael E. (2000) 'Conforming to Europe: The Domestic Impact of European Foreign Policy Cooperation', Journal of European Public Policy 7(4): 613-31.

Smith, Michael E. (2001a) 'Diplomacy by Decree: The Legalization of EU Foreign Policy', Journal of Common Market Studies 39(1): 79-104.

Smith, Michael E. (2001b) 'The Quest for Coherence: Institutional Dilemmas of External Action from Maasricht to Amsterdam', in Alec Stone Sweet, Wayne Sandholtz and Neil Fligstein (eds) The Institutionalization of Europe. Oxford: Oxford University Press.

Smith, Michael E. (2003) Europe's Foreign and Security Policy: The Institutionalization of Cooperation. Cambridge: Cambridge University Press.

Snidal, Duncan (1991) 'Relative Gains and the Pattern of International Cooperation', American Political Science Review 85(3): 701-26.

Spencer, Claire (2001) 'The EU and Common Strategies: The Revealing Case of the Mediterranean', European Foreign Affairs Review 6(1): 31-51.

Stavridis, Stelios and Christopher Hill (eds) (1996) Domestic Sources of Foreign Policy: Western European Reactions to the Falklands Conflict. Oxford: Berg Publishers.

Stone Sweet, Alec and Wayne Sandholtz (1998) 'Integration, Supranational Governance, and the Institutionalization of the European Polity', in Wayne Sandholtz and Alec Stone Sweet (eds) European Integration and Supranational Governance, pp. 1-26. Oxford: Oxford University Press.

Thelen, Kathleen and Sven Steinmo (1992) 'Historical Institutionalism in Comparative Politics', in Sven Steinmo, Kathleen Thelen and Frank Longstreth (eds) Structuring Politics: Historical Institutionalism in Comparative Analysis, pp. 1-33. Cambridge: Cambridge University Press.

Tietje, Christian (1997) 'The Concept of Coherence in the Treaty on European Union and the Common Foreign and Security Policy', European Foreign Affairs Review 2(2): 211-33.

Tonra, Ben (1997) 'The Impact of Political Cooperation', in Knud Erik Jörgensen (ed.) Reflective Approaches to European Governance, pp. 181-200. Basingstoke: Macmillan.

Tonra, Ben (2000) 'Committees in Common: Comitology and the Common Foreign and Security Policy', in Thomas Christiansen and Emil Kirchner (eds) Committee Governance in the European Union. Manchester: Manchester University Press.

Tonra, Ben (2001) The Europeanisation of National Foreign Policy: Dutch, Danish and Irish Foreign Policy in the European Union. Aldershot: Ashgate.

van Praag, Nicholas (1982) 'European Political Cooperation and Southern Africa', in David Allen, Reinhardt Rummel and Wolfgang Wessels (eds) European Political Cooperation: Towards a Foreign Policy for Western Europe, pp. 134-46. London: Butterworths.

von der Gablentz, Otto (1979) 'Luxembourg Revisited, or the Importance of European Political Cooperation', Common Market Law Review 16(4): 685-99. 
Wallace, Helen and Geoffrey Edwards (1976) 'European Community: The Evolving Role of the Presidency of the Council', International Affairs 53(4): 535-50.

Wallace, William (1982) 'National Inputs into European Political Cooperation', in David Allen, Reinhardt Rummel and Wolfgang Wessels (eds) European Political Cooperation: Towards a Foreign Policy for Western Europe, pp. 46-59. London: Butterworths.

Wallace, William (1983) 'Introduction: Cooperation and Convergence in European Foreign Policy', in Christopher Hill (ed.) National Foreign Policies and European Political Cooperation, pp. 1-16. London: George Allen \& Unwin.

Wendt, Alexander (1987) 'The Agent-Structure Problem in International Relations Theory', International Organization 41(3): 335-70.

Wendt, Alexander (1994) 'Collective Identity Formation and the International State', American Political Science Review 88(2): 384-96.

Wendt, Alexander (1995) 'Constructing International Politics', International Security 20(1): 71-81.

Wessels, Wolfgang (1982) 'European Political Cooperation: A New Approach to European Foreign Policy', in David Allen, Reinhardt Rummel and Wolfgang Wessels (eds) European Political Cooperation: Towards a Foreign Policy for Western Europe, pp. 1-20. London: Butterworths.

White, Brian (1999) 'The European Challenge to Foreign Policy Analysis', European Journal of International Relations 5(1): 37-66.

Whitman, Richard (1998) From Civilian Power to Superpower? The International Identity of the European Union. London: Macmillan.

Zielonka, Jan (1998) Explaining Euro-Paralysis: Why Europe is Unable to Act in International Politics. New York: St. Martin's Press. 